\title{
Structure and spatial distribution of the rotifer assemblages along a tropical reservoir
}

\author{
T. A. S. Santos ${ }^{a}$ (D) F. A. Lansac-Tôha ${ }^{b *}$ (D), T. Mantovano ${ }^{b}$ (D), E. O. Conceição ${ }^{b}$ (D), \\ L. T. F. Schwind ${ }^{b}$ (D), R. L. Arrieirac (1), J. C. Lima ${ }^{a}$ (1) and M. Serafim-Junior ${ }^{a}$ \\ ${ }^{a}$ Centro de Ciências Agrárias, Ambientais e Biológicas, Universidade Federal do Recôncavo da Bahia - UFRB, \\ Campus Universitário, Rua Rui Barbosa, 710, CEP 44380-000, Cruz das Almas, BA, Brasil \\ brograma de Pós-graduação em Ecologia de Ambientes Aquáticos Continentais - PEA, Núcleo de Pesquisas em \\ Limnologia Ictiologia e Aquicultura - Nupélia, Universidade Estadual de Maringá - UEM, Av. Colombo, 5790, \\ CEP 87020-900, Maringá, PR, Brasil \\ 'Universidade Paranaense - UNIPAR, Praça Mascarenhas de Moraes, 4282, CEP 87502-080, Umuarama, PR, Brasil \\ *e-mail: fabio@nupelia.uem.br
}

Received: July 22, 2019 - Accepted: December 2, 2019 - Distributed: May 31, 2021

(With 5 figures)

\begin{abstract}
The construction of reservoirs is a common practice in the world. These systems modify the hydric landscape and alter the flow of rivers, becoming lotic environments in lentic. Here we investigated the structure and spatial distribution of rotifers along a tropical reservoir. We sampled four points in the Pedra do Cavalo Reservoir, Bahia, Brazil, bimonthly, between August 2014 and June 2015. We registered more than 70 taxa distributed in 17 families, with the majority of species belonging to the Lecanidae, Brachionidae and Trichocercidae families. The species rarefaction curve did not achieve a total asymptote, indicating that species richness in the reservoir is higher than what was registered. Based in the species frequency of occurrence, we identified 48 rare species, 16 common species, five constant species and one frequent species. The highest beta diversity values were registered in riverine P1 (0.513) and intermediate P2 (0.503), although there were no significant differences between the sampling points. Despite the high abundance values in P1, P2 and P3 no significant differences were found between the studied points. Thus, this study substantially increases the knowledge on the rotifer community in the Paraguaçu River and contributes to future studies that focus on biodiversity, ecology and conservation in the Brazilian reservoir ecosystems.
\end{abstract}

Keywords: plankton, rotifera, beta diversity, longitudinal distribution.

\section{Estrutura e distribuição espacial da comunidade de rotíferos em um reservatório tropical}

\section{Resumo}

A construção de reservatórios é uma prática comum no mundo. Esses sistemas modificam a paisagem hídrica e alteram o fluxo dos rios, tornando-se ambientes lóticos em lênticos. Aqui investigamos a estrutura e distribuição espacial de rotíferos ao longo de um reservatório tropical. Foram amostrados quatro pontos no Reservatório da Pedra do Cavalo, Bahia, Brasil, bimestralmente, entre agosto de 2014 e junho de 2015. Registramos mais de 70 táxons distribuídos em 17 famílias, com a maioria das espécies pertencentes às famílias Lecanidae, Brachionidae e Trichocercidae. A curva de rarefação das espécies não alcançou uma assíntota total, indicando que a riqueza de espécies no reservatório é superior à registrada. Com base na frequência de ocorrência das espécies, identificamos 48 espécies raras, 16 espécies comuns, cinco espécies constantes e uma espécie frequente. Os maiores valores de diversidade beta foram registrados no ribeirinho P1 $(0,513)$ e no intermediário P2 (0,503), embora não houvesse diferenças significativas entre os pontos de amostragem. Apesar dos altos valores de abundância em P1, P2 e P3, não foram encontradas diferenças significativas entre os pontos estudados. Assim, este estudo aumenta substancialmente o conhecimento sobre a comunidade de rotíferos no rio Paraguaçu e contribui para estudos futuros que enfocam biodiversidade, ecologia e conservação nos ecossistemas de reservatórios brasileiros.

Palavras-chave: plâncton, rotifera, diversidade beta, distribuição longitudinal.

\section{Introduction}

The freshwater environments represent vital resources for human, also an ideals habitat for the maintenance of the biota and endemic species (Vörösmarty et al., 2010;
Junk et al., 2014). These hydric systems are formed by lentic environments with slow or absence of flow (as lakes); lotic with flow (as rivers), and semilotic environments, 
with calm water that preserve characteristics of lotic environments (as reservoirs) (Esteves, 2011).

The construction of reservoirs is also a common practice in tropical and subtropical regions of South America, facilitated by high hydric availability, and their reasons are for electricity generation, as well urban, industrial and agricultural water supply, leisure and navigation (Rodgher et al., 2005). In Brazil, the increase in reservoir numbers started in the 1960's (Agostinho et al., 2002; Dudgeon et al., 2006), which have modified the hydric landscape and the flow of lotic environments, becoming lentic areas (Nogueira, 2006; Jorgensen et al., 2013; Schork and Zaniboni-Filho, 2018). Currently there are over 1,313 large reservoirs in operation and an enormous number of small all over the country (Dias et al., 2018).

The reduction of hydrologic flow provides favorable conditions to the development of species adapted to lentic conditions (Rocha et al., 1999). Such environments, as reservoirs, are suitable for the development of high planktonic populations, once that the plankton growing rates are elevated in these environments (Marzolf, 1990; Okulu et al., 2016). Studies have shown that high densities of zooplanktonic organisms in reservoirs may be due to the reduced water speed and low water residence time with the associated reduction in advective downstream losses (Takahashi et al., 2014; Beaver et al., 2015; Okulu et al., 2016). Besides that, the zooplankton abundance, generally, exhibited a trend similar that of the phytoplankton (Beaver et al., 2015).

Studies on the structure and functioning of the planktonic community in reservoirs provide opportunities to investigate patterns due to the cyclic variation and episodic disturbances (Nogueira, 2001; Xue et al., 2018). Reservoir shows marked changes in limnological conditions in relatively short periods (Geraldes and George, 2013). Thus, the understanding of the plankton dynamics in these systems can be used to evaluate the resilience of this type of ecosystem, once plankton are sensible to alterations in environmental characteristics and reflect the dynamics of the ecosystem (Margalef, 1983; Legendre et al., 1985; Dias et al., 2012; Silva Brito et al., 2018).

The zooplanktonic community has a fundamental role in aquatic ecosystems, due to its position in the food chain, where it regulates the structural heterogeneity of various biological communities (Lemke and Benke, 2009). Among the zooplankton, rotifers constitute the majority of the species richness, as they occupy diverse ecological niches, both in the limnetic and littoral zones (Lansac-Tôha et al., 2009; Azevêdo et al., 2015). Furthermore, because the environmental requirements their immediately respond to the environmental variations, associated with high rates of population renovation (Obertegger et al., 2007; Azevêdo et al., 2015).

In this way, characterizing the community structure of rotifers is useful both to the understanding of the growth of dependent populations and for studies aiming at conservation and biomonitoring in this region. This study aimed at investigating the structure and spatial distribution of the rotifer community along a tropical reservoir.

\section{Material and Methods}

\subsection{Study area}

This study was made in the Pedra do Cavalo Reservoir, which supply a power plant in the dam $\left(12^{\circ} 35^{\prime} \mathrm{S}\right.$ and $38^{\circ} 59^{\prime} \mathrm{W}$ ). This lake of $55 \mathrm{Km}^{2}$ area is in Bahia (Brazil) in the lower part of the Paraguaçu River, which large tributary is the Jacuípe River. This river rises in Chapada Diamantina Mountain, drain and crosses the semiarid region for $500 \mathrm{~km}$ until the confluence with the Paraguaçu River near the Pedra do Cavalo Reservoir (Fontes et al., 2011) (Figure 1).

We performed six samplings bimonthly between August 2014 and June 2015 in four sites distributed in the littoral zone of the Pedra do Cavalo Reservoir (Table 1).

\subsection{Sampling design}

We sampled rotifers in the morning period, at the sub-surface of the pellagic zone, using a graduated bucket and plankton net of $68 \mu \mathrm{m}$ mesh size. We filtered 100 liters of water per sample totalizing 6 replicated. Samples were fixed with a $4 \%$ formaldehyde solution and buffered with calcium carbonate precipitated.

\subsection{Laboratory analyses}

Organisms were analyzed using stereoscope and microscope. We determined rotifer species richness in each sample until species curve was stabilized, that is, until no new species were registered in the sample. The individuals were estimated by analyzing a minimum of three subsamples (Bottrell et al., 1976) in a Sedgewick-Rafter chamber, using an optical microscope, at least 50 individuals being counted. Samples with few individuals were counted integrally. Species were identified using slides and coverslips and following basic literature as Koste $(1972,1978)$, Koste and Roberton (1983), Paggi (1989), Nogrady et al. (1993), Nogrady and Pourriot (1995) and Segers (1995).

In order to determine the abundance of rotifers (individuals $/ \mathrm{m}^{3}$ ), we have taken subsamples from 0.5 to $4 \mathrm{ml}$ with a graduated pipette after sample homogenization and counted in the Sedgwick-Rafter chamber under optic and stereoscopic microscope.

\subsection{Data analyses}

We have determined the frequency of occurrence of species considering the number of samples in which the species was present in relation to the total of samples. This was calculated according to the Formula 1:

$C=p \times 100 / P$

where $\mathrm{C}$ is the constancy index, $\mathrm{p}$ is the number of samples where the species was present and $\mathrm{P}$ is the total of samples.

Then, we have classified species as constant (present in more than $80 \%$ of samples), frequent (between 50 and $80 \%$ ), common (from 20 to $50 \%$ ), and rare $(<20 \%)$ (Castilho et al., 2016).

Through species presence and absence data, we generated a rarefaction curve to verify if the samples were sufficient to estimate the incidence of rotifer species. We calculated 


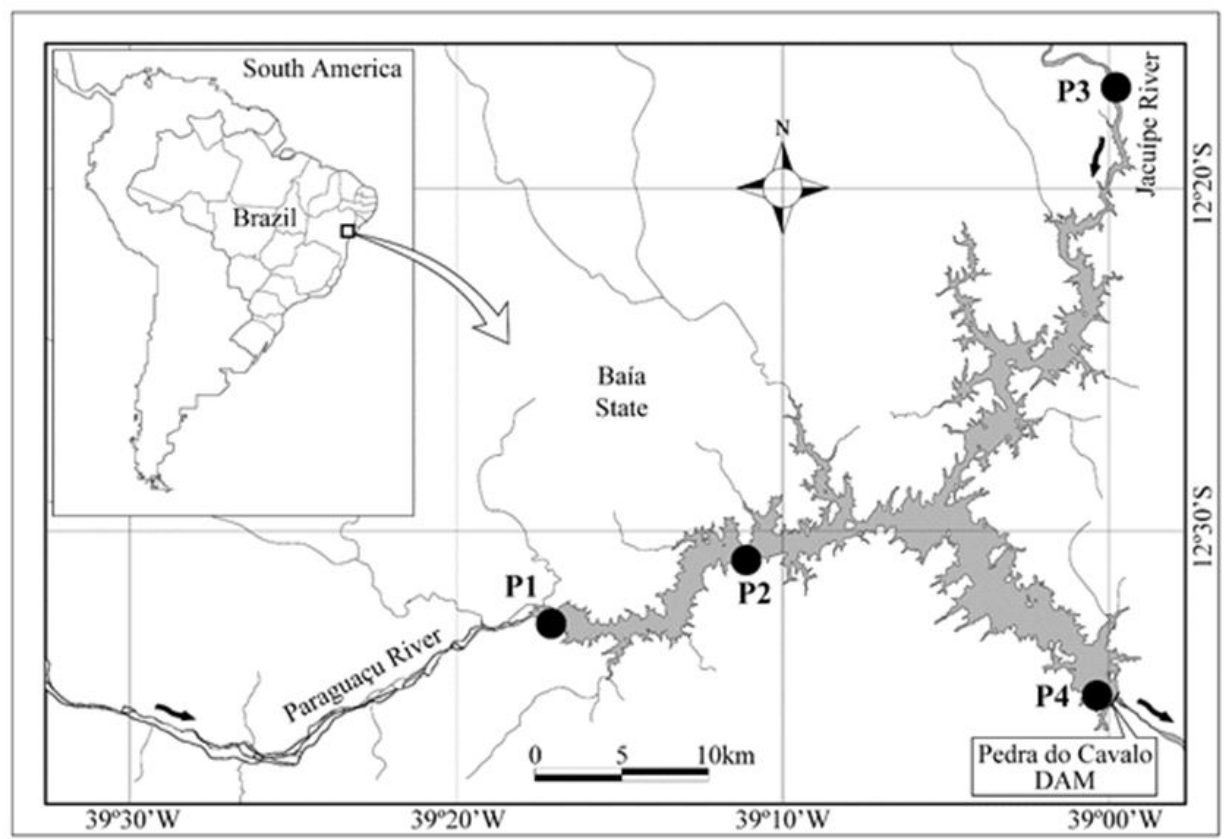

Figure 1. Study area with sampled points in the Paraguaçu River and reservoir of the Pedra do Cavalo.

Table 1. Environmental characterization of sampled points in the Pedra do Cavalo reservoir.

\begin{tabular}{|c|c|}
\hline Sampled points & Environmental characterization \\
\hline $\begin{array}{c}\text { P1-Reservoir/Tupiaçu } \\
\left(12^{\circ} 32^{\prime} 44.9^{\prime \prime} \mathrm{S} ; 39^{\circ} 17^{\prime} 05.2^{\prime} \mathrm{W}\right)\end{array}$ & $\begin{array}{l}\text { In the surroundings of } \mathrm{P} 1 \text {, agro pastoral activities as sheep farming and } \\
\text { okra, manioc, sugar cane, corn and tobacco plantations are common. } \\
\text { Alkaline water }(\mathrm{pH}=8.2) \text {, lowest average value recorded for electrical } \\
\text { conductivity }\left(144 \mu \mathrm{S} / \mathrm{cm}^{-1}\right) \text {, total dissolved solids }(72 \mathrm{mg} / \mathrm{L}) \text {. }\end{array}$ \\
\hline $\begin{array}{c}\text { P2-Reservoir/Balsa } \\
\left(12^{\circ} 30^{\prime} 49.4 " \mathrm{~S} ; 39^{\circ} 11^{\prime} 14.1^{\prime} \mathrm{W}\right)\end{array}$ & $\begin{array}{l}\text { Fish farming in net tanks, recreation and transport of people and } \\
\text { automobiles by ferryboat. Possess macrophyte patches, } \mathrm{pH}=7.8 \text {, electrical } \\
\text { conductivity }\left(171 \mu \mathrm{S} / \mathrm{cm}^{-1}\right) \text {, total dissolved solids }(92 \mathrm{mg} / \mathrm{L}) \text {. }\end{array}$ \\
\hline $\begin{array}{l}\text { P3-Reservoir/Feira de Santana } \\
\left(12^{\circ} 35^{\prime} 31.2^{\prime} \mathrm{S} ; 38^{\circ} 59^{\prime} 01.1 \mathrm{~W}\right)\end{array}$ & $\begin{array}{l}\text { Localized in the municipality of Feira de Santana (Jacuípe River), next to } \\
\text { houses without basic sanitation, where it is possible to observe the discharge } \\
\text { of domestic sewage. Possess macrophyte patches. } \mathrm{pH}=7.7 \text {, electrical } \\
\text { conductivity }\left(250 \mu \mathrm{S} / \mathrm{cm}^{-1}\right) \text {, total dissolved solids }(134 \mathrm{mg} / \mathrm{L}) \text {. }\end{array}$ \\
\hline $\begin{array}{l}\text { P4-River Reservoir/Piscicultura } \\
\left(12^{\circ} 41^{\prime} 03.0^{\prime} \mathrm{S} ; 38^{\circ} 51^{\prime} 36.8^{\prime \prime} \mathrm{W}\right)\end{array}$ & $\begin{array}{l}\text { Next to the dam and to the catch pump of the fish farm station Rodolpho } \\
\text { Von Ihering. Possess macrophyte patches, } \mathrm{pH}=7.4 \text {, electrical conductivity } \\
\left(250,1 \mu \mathrm{S} / \mathrm{cm}^{-1}\right) \text {, ), total dissolved solids }(194 \mathrm{mg} / \mathrm{L}) \text {. }\end{array}$ \\
\hline
\end{tabular}

the mean percentage of richness extrapolation according to Heck Junior et al. (1975). We have used the Jackknife 2 estimator, which bases in the removal of a sample from the total of observed samples, recalculating the estimator from the remaining values. For this, we used the programs Estimate and Statistica 5.0.

Firstly we used an analysis of variance (ANOVA) in order to test for differences in the abundance and richness of species between sampled points (P1, P2, P3 and P4). However, as the homocedasticity assumptions for the ANOVA were not achieved, we realized a non-parametric Kruskal-Wallis test (Sokal and Rohlf, 1995).

We have evaluated the variability of the composition of the rotifer community (beta diversity) through a test for homogeneity of multivariate dispersions - PERMDISP (Anderson et al., 2006) using presence/absence data. This test is based on the distances between the sample units and the centroid of the group in an Analysis of Principal Coordinates (PCoA), built using a dissimilarity measure. For this we have used the Jaccard dissimilarity measure, so that the higher the Jaccard dissimilarity means, the higher the beta diversity. PERMDISP uses an ANOVA with 999 permutations to test for significant differences $(\mathrm{p}<0.05)$. For PERMDISP and PCoA, we used the software R 3.4 (R Development Core Team, 2017), and the packages vegan (Oksanen et al., 2013) and permute (Simpson, 2016).

\section{Results}

The rotifer assembly was composed by 70 taxa, distributed in 17 families (Table 2). The richest families were: Lecanidae (17 taxa), Brachionidae (14 taxa), and Trichocercidae (eight taxa) (Table 2). 
Table 2. Faunistic inventory of the rotifer community in the reservoir Pedra do Cavalo.

\begin{tabular}{|c|c|c|c|c|}
\hline & P1 & P2 & $\mathbf{P 3}$ & P4 \\
\hline \multicolumn{5}{|l|}{ Brachionidae } \\
\hline Brachionus angularis Gosse, 1851 & $\mathrm{X}$ & $\mathrm{X}$ & $\mathrm{X}$ & \\
\hline Brachionus calyciflorus Pallas, 1766 & $\mathrm{X} 4$ & $\mathrm{X}$ & $\mathrm{X}$ & $\mathrm{X}$ \\
\hline Brachionus caudatus Barrois \& Daday, 1894 & $\mathrm{X}$ & $\mathrm{X}$ & & \\
\hline Brachionus falcatus Zacharias, 1898 & $\mathrm{X}$ & $\mathrm{X}$ & & \\
\hline Brachionus havanaensis Rousselet, 1911 & $\mathrm{X}$ & $\mathrm{X}$ & & \\
\hline Brachionus quadridentatus Hermann, 1783 & $\mathrm{X}$ & & $\mathrm{X}$ & \\
\hline Brachionus urceolaris Muller, 1773 & $\mathrm{X}$ & $\mathrm{X}$ & & \\
\hline Brachionus mirus Daday, 1905 & & $\mathrm{X}$ & & \\
\hline Keratella americana Carlin, 1943 & $\mathrm{X}$ & $\mathrm{X}$ & $\mathrm{X}$ & $\mathrm{X}$ \\
\hline Keratella cochlearis (Gosse, 1851) & $\mathrm{X}$ & $\mathrm{X}$ & $\mathrm{X}$ & $\mathrm{X}$ \\
\hline Keratella lenzi Hauer, 1953 & $\mathrm{X}$ & $\mathrm{X}$ & $\mathrm{X}$ & $\mathrm{X}$ \\
\hline Keratella tropica (Apstein, 1907) & $\mathrm{X}$ & $\mathrm{X}$ & $\mathrm{X}$ & $\mathrm{X}$ \\
\hline Platyias quadricornis (Ehrenberg, 1832) & $\mathrm{X}$ & $\mathrm{X}$ & $\mathrm{X}$ & $\mathrm{X}$ \\
\hline Plationus patulus (Muller, 1786) & $\mathrm{X}$ & $\mathrm{X}$ & $\mathrm{X}$ & $\mathrm{X}$ \\
\hline \multicolumn{5}{|l|}{ Conochilidae } \\
\hline Conochilus coenobasis (Skorikov, 1914) & & & $\mathrm{X}$ & \\
\hline Conochilus dossuarius Hudson, 1885 & & $\mathrm{X}$ & & \\
\hline Conochilus cf. unicornis Rousselet, 1892 & & $\mathrm{X}$ & & \\
\hline \multicolumn{5}{|l|}{ Dicranophoridae } \\
\hline Dicranophorus epicharis Harring \& Myers, 1928 & & & & $\mathrm{X}$ \\
\hline \multicolumn{5}{|l|}{ Epiphanidae } \\
\hline Epiphanes clavatula (Ehrenberg, 1832) & $\mathrm{X}$ & $\mathrm{X}$ & $\mathrm{X}$ & $\mathrm{X}$ \\
\hline \multicolumn{5}{|l|}{ Euchlanidae } \\
\hline Dipleuchlanis propatula (Gosse, 1886) & $\mathrm{X}$ & & $\mathrm{X}$ & \\
\hline Euchlanis dilatata Ehrenberg, 1832 & & $\mathrm{X}$ & $\mathrm{X}$ & $\mathrm{X}$ \\
\hline Euchlanis meneta Myers, 1930 & $\mathrm{X}$ & $\mathrm{X}$ & $\mathrm{X}$ & $\mathrm{X}$ \\
\hline Euchlanis lyra Hudson, 1886 & & $\mathrm{X}$ & & \\
\hline \multicolumn{5}{|l|}{ Filinidae } \\
\hline Filinia longiseta (Ehrenberg, 1834) & $\mathrm{X}$ & $\mathrm{X}$ & & \\
\hline \multicolumn{5}{|l|}{ Gastropodidae } \\
\hline Gastropus hyptopus (Ehrenberg, 1938) & & & $\mathrm{X}$ & \\
\hline \multicolumn{5}{|l|}{ Lecanidae } \\
\hline Lecane bulla (Gosse, 1886) & $\mathrm{X}$ & $\mathrm{X}$ & $\mathrm{X}$ & $\mathrm{X}$ \\
\hline Lecane cornuta (Muller 1786) & $\mathrm{X}$ & $\mathrm{X}$ & $\mathrm{X}$ & $\mathrm{X}$ \\
\hline Lecane curvicornis (Murray, 1913) & $\mathrm{X}$ & $\mathrm{X}$ & $\mathrm{X}$ & $\mathrm{X}$ \\
\hline Lecane elsa Hauer, 1931 & $\mathrm{X}$ & & & $\mathrm{X}$ \\
\hline Lecane haliclysta Harring \& Myers, 1926 & $\mathrm{X}$ & & $\mathrm{X}$ & \\
\hline Lecane hastata (Murray, 1913) & $\mathrm{X}$ & & & \\
\hline Lecane leontina (Turner, 1892) & $\mathrm{X}$ & $\mathrm{X}$ & $\mathrm{X}$ & $\mathrm{X}$ \\
\hline Lecane ludwigii (Eckstein, 1883) & $\mathrm{X}$ & $\mathrm{X}$ & $\mathrm{X}$ & $\mathrm{X}$ \\
\hline Lecane luna (Muller, 1776) & $\mathrm{X}$ & $\mathrm{X}$ & $\mathrm{X}$ & $\mathrm{X}$ \\
\hline Lecane lunaris (Ehrenberg, 1832) & & & $\mathrm{X}$ & $\mathrm{X}$ \\
\hline Lecane monostyla (Daday, 1897) & $\mathrm{X}$ & & $\mathrm{X}$ & \\
\hline Lecane papuana Murray, 1913 & & & $\mathrm{X}$ & \\
\hline Lecane quadridentata (Ehrenberg, 1830) & $\mathrm{X}$ & $\mathrm{X}$ & $\mathrm{X}$ & $\mathrm{X}$ \\
\hline Lecane rhytida Harring e Myers, 1926 & & $\mathrm{X}$ & & \\
\hline Lecane spinulifera (Edmondson, 1935) & & & & $\mathrm{X}$ \\
\hline
\end{tabular}


Table 2. Continued...

\begin{tabular}{|c|c|c|c|c|}
\hline & P1 & $\mathbf{P 2}$ & P3 & $\mathbf{P 4}$ \\
\hline Lecane stenroosi (Meissner, 1908) & $\mathrm{X}$ & & & \\
\hline Lecane stichaea Hairing, 1913 & & $\mathrm{X}$ & $\mathrm{X}$ & \\
\hline \multicolumn{5}{|l|}{ Lepadellidae } \\
\hline Lepadella benjamini Harring, 1916 & & & $\mathrm{X}$ & \\
\hline Lepadella ovalis (Muller,1786) & & $\mathrm{X}$ & $\mathrm{X}$ & $\mathrm{X}$ \\
\hline \multicolumn{5}{|l|}{ Mytilinidae } \\
\hline Mytilina mucronata Muller, 1773 & $\mathrm{X}$ & $\mathrm{X}$ & $\mathrm{X}$ & $\mathrm{X}$ \\
\hline Mytilina ventralis (Ehrenberg, 1832) & & & $\mathrm{X}$ & \\
\hline \multicolumn{5}{|l|}{ Notommatidae } \\
\hline Cephalodella gibba (Ehrenberg, 1832) & & $\mathrm{X}$ & $\mathrm{X}$ & \\
\hline Cephalodella tenuiseta (Burn, 1890) & $\mathrm{X}$ & & & \\
\hline Notommata cerberus (Gosse, 1886) & & & $\mathrm{X}$ & \\
\hline Notommata copeus Ehrenberg, 1834 & & & $\mathrm{X}$ & $\mathrm{X}$ \\
\hline \multicolumn{5}{|l|}{ Scaridiidae } \\
\hline Scaridium longicaudum (Muller, 1786) & & & & $\mathrm{X}$ \\
\hline \multicolumn{5}{|l|}{ Synchaetidae } \\
\hline Polyarthra dolichoptera Idelson, 1925 & & & & $\mathrm{X}$ \\
\hline Polyarthra vulgaris Carlin, 1943 & & & & $\mathrm{X}$ \\
\hline Synchaeta stylata Wierzejski, 1893 & & $\mathrm{X}$ & & \\
\hline \multicolumn{5}{|l|}{ Testudinellidae } \\
\hline Testudinella patina (Hermann, 1783) & $\mathrm{X}$ & $\mathrm{X}$ & $\mathrm{X}$ & $\mathrm{X}$ \\
\hline \multicolumn{5}{|l|}{ Trichocercidae } \\
\hline Trichocerca bicristata (Gosse, 1887) & $\mathrm{X}$ & & & \\
\hline Trichocerca bidens (Lucks, 1912) & & $\mathrm{X}$ & $\mathrm{X}$ & \\
\hline Trichocerca capucina (Wierzejski e Zacharias, 1893) & & & $\mathrm{X}$ & $\mathrm{X}$ \\
\hline Trichocerca elongata braziliensis (Murray, 1913) & & & $\mathrm{X}$ & \\
\hline Trichocerca heterodactila (Tschugunoff, 1921) & & & $\mathrm{X}$ & \\
\hline Trichocerca insignis (Herrick, 1885) & $\mathrm{X}$ & & $\mathrm{X}$ & \\
\hline Trichocerca intermédia (Stenroos, 1898) & & & $\mathrm{X}$ & \\
\hline Trichocerca pusilla (Jennings, 1903) & $\mathrm{X}$ & $\mathrm{X}$ & $\mathrm{X}$ & $\mathrm{X}$ \\
\hline \multicolumn{5}{|l|}{ Trichotriidae } \\
\hline Macrochaetus sericus (Thorpe, 1893) & $\mathrm{X}$ & $\mathrm{X}$ & $\mathrm{X}$ & $\mathrm{X}$ \\
\hline Trichotria tetractis (Ehrenberg, 1830) & $\mathrm{X}$ & $\mathrm{X}$ & $\mathrm{X}$ & \\
\hline \multicolumn{5}{|l|}{ Trochosphaeridae } \\
\hline Horaella thomassoni Koste, 1973 & & & $\mathrm{X}$ & \\
\hline Bdelloidea & $\mathrm{X}$ & $\mathrm{X}$ & $\mathrm{X}$ & $\mathrm{X}$ \\
\hline
\end{tabular}

We found no significant differences in rotifer abundance between sampled points $(\mathrm{p}>0.05)$ (Figure 2A). Brachionidae, Lecanidae, and Synchaetidae were the most abundant families. Among the taxa, Keratella cochlearis $\left(961.648,8 \mathrm{ind} / \mathrm{m}^{3}\right)$ and Brachionus calyciflorus $\left(251.953,4 \mathrm{ind} / \mathrm{m}^{3}\right)$ presented the highest abundance peaks (Figure 2B).

We verified no significant differences in species richness between sampled points $(\mathrm{p}<0.05)$ (Figure 3$)$. The frequency of occurrence indicated a higher number of rare species (48 species), followed by common species (16 species), frequent species (five species: Keratella tropica $73.9 \%$, Lecane bulla 69.5\%, Keratella cochlearis $69.5 \%$, Brachionus calyciflorus $60.8 \%$ e Keratella americana $60.8 \%$ ), and one constant taxa, belonging to the Bdelloidea (91.3\%).

The rarefaction curve evidenced that our samplings were not enough to reach an asymptotic trend in P2, P3 and P4 (Figure 4). However more samples are needed to reach a $\mathrm{P} 1$ asymptote.

According to the mean percentage of richness extrapolation, rotifer data were capable of assessing $62.4 \%$ of species. The PERMDISP test, used to verify beta diversity, revealed higher values in P1 (0.513) and P2 (0.503), without significant differences between points (Figure 5). 
A

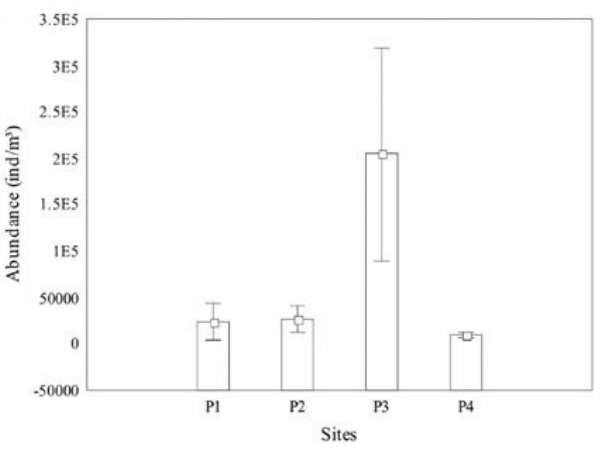

B

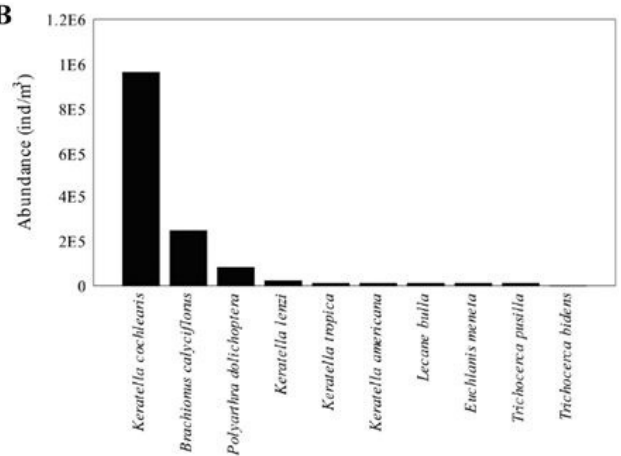

Figure 2. Abundance of the community in sampled points (A) and more abundant rotifer species (B) in the reservoir of the Pedra do Cavalo.

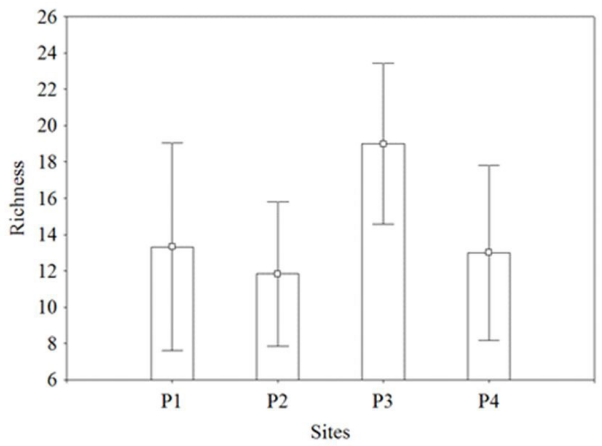

Figure 3. Mean and standard deviation of rotifer species richness in the reservoir of the Pedra do Cavalo between August 2014 and June 2015.

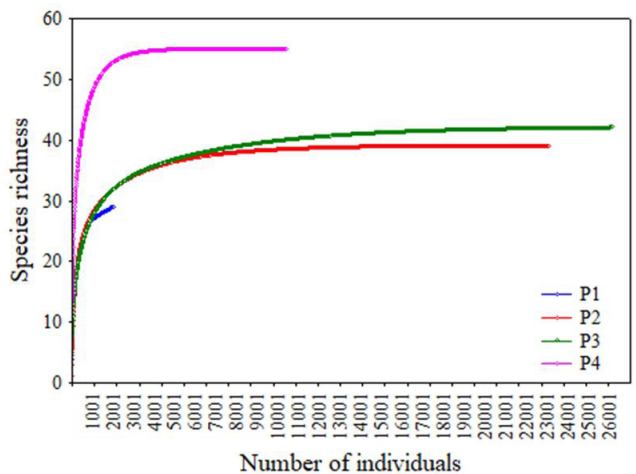

Figure 4. Rarefaction curve of rotifer species based on richness, sampled points, and richness estimator Jack 2.

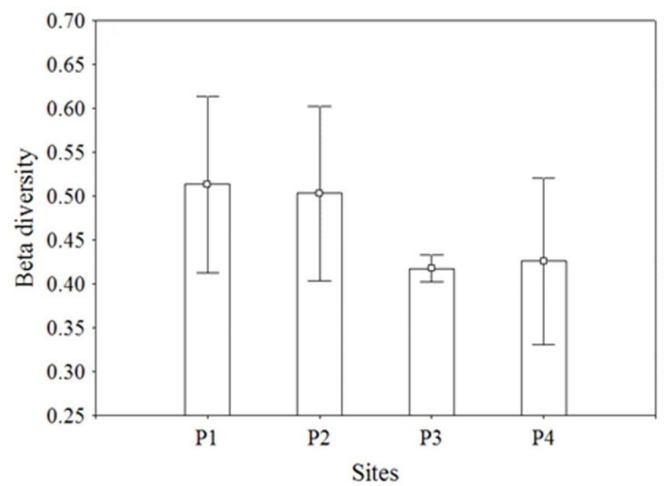

Figure 5. Principal Coordinates Analysis (PCoA) showing the similarity in species composition between the sampled points.

\section{Discussion}

The results obtained through the faunistic inventory of the rotifer community showed that the number of taxa may be considered relevant when compared to the values found in other studies. Sampaio et al. (2002), for example, identified 76 species of Rotifera in seven reservoirs of the Paranapanema River - SP/PR; Serafim-Junior et al. (2010) registered 52 taxa in seven sampled points in the Iraí Reservoir - PR; and Pedrozo et al. (2012) identified 57 taxa in seven sampled points in the mesotrophic Dona Francisca Reservoir - RS. Comparing with reservoirs in the same region (semi-arid region) like as Armando Ribeiro Gonçalves, Boqueirão de Parelhas, Gargalheiras, Itans, Passagem das Traíras, and Sabugi (Eskinazi-Sant'Anna et al., 2013) our study also showed a high number of taxa.

High abundances of $K$. cochlearis and B. calyciflorus have been commonly registered in reservoirs and are possibly related to the great tolerance of these species to eutrophic environments (Aoyagui et al., 2004; Almeida et al., 2006; Bezerra et al., 2015), especially in the studied region (Almeida et al., 2012). Some species Keratella are good explorers of a high range of feeding resources and are resistant to cyanobacteria toxins, which favors the development of large populations in eutrophic environments (Bezerra et al., 2015). Brachionus calyciflorus is tolerable to eutrophic environments with high conductivity (Serafim-Junior et al., 2010). Thus, water quality changes in reservoirs resulting from the eutrophication process may have contributed to the higher abundance of these species.

Brachionidae, Lecanidae, and Trichocercidae have been frequently registered in various studies in Brazil and others countries as the families with the highest species richness, and may correspond to $50 \%$ of the present taxa (Lansac-Tôha et al., 2004, 2009; Mantovano et al., 2015; Augustin et al., 2018; Nandini et al. 2019). The predominance of these families is considered typical of Neotropical regions (Serafim Júnior et al., 2003; Aoyagui et al., 2004).

Lecanidae presented the highest species richness and was mainly registered in P2, P3 and P4, which possess macrophyte patches. Taxa of these families are 
more frequent in the littoral zone, and in the benthonic and periphytic communities. They usually occur in the plankton as occasional migrants, mainly in areas with marginal vegetation and extensive macrophyte patches (Almeida et al., 2006; Melo-Junior et al., 2007; Bezerra et al., 2015). On the other hand, Brachionidae, highly endemic to South America, have in general planktonic habit and are associated with environments with great accumulation of organic matter (Almeida et al., 2006; Dantas-Silva and Dantas, 2012). Thus, the higher richness of this family in the reservoir is expected, since three sampled points present some kind of activities that could generate nutrient accumulation (see Table 1).

The highest frequency of occurrence of Keratella tropica, Lecane bulla, Keratella cochlearis, Brachionus calyciflorus, Keratella americana and Bdelloidea is commonly observed in other continental water bodies of the tropical region. As in our study, Eler et al. (2003) observed an elevated frequency of occurrence for $K$. cochlearis, $K$. tropica and Bdelloidea in fee fishing lakes, in the Mogi-Guaçu River Basin (SP). Serafim-Junior et al. (2006) have also registered highest frequency of occurrence for $K$. cochlearis and L. bulla, besides more Bdelloidea, with $100 \%$ of occurrence in the Itajaí-Açu River at Santa Catarina State. Keratella tropica and K. americana were the dominant species in the zooplankton community of some semi-arid reservoirs of the Rio Grande do Norte State (Eskinazi-Sant'Anna et al., 2007). High frequencies of $B$. calyciflorus and $K$. cochlearis have also been commonly observed in reservoirs (Zaganini et al., 2011; Dantas-Silva and Dantas, 2012; Pedrozo et al., 2012). Serafim-Junior et al. (2016), studying the effects of a reservoir construction in the Iguaçu River (PR) on zooplankton also verified an elevated frequency for $K$. americana and $K$. cochlearis.

Although the number of rotifer species is considerably high, the species rarefaction curve did not reach a total asymptote, indicating that species richness in the reservoir is higher than has been registered. According to the mean percentage of richness extrapolation, our rotifer data were capable of assessing $62.4 \%$ of species. However, Heck Junior et al. (1975) suggested that inventories that obtain $50 \%$ to $75 \%$ of the total number of species that occur in a determinate area might be considered satisfactory without loss of information, provided that common species are registered in the study.

Our results evidenced no significant differences between sampled points for beta diversity. This may be a result of the high water residence time (180 days) that the Pedra do Cavalo Reservoir presents when compared to other small and medium sized reservoirs, such as Rosana Reservoir (18.6 days) and Salto Segredo (47 days) (Julio Junior et al., 2005). Environments with low flow velocity and long residence times, such as reservoirs, favor rotifers, as they are organisms with a short life cycle (Takahashi et al., 2014).

The Paraguaçu River, with its $500 \mathrm{Km}$ of extension, still remains unknown as to its planktonic species, as rotifers. In this sense, we highlight the importance of realizing a spatially integrated analysis, rich in information on local species. This study substantially amplifies the knowledge of the rotifer communities in the Paraguaçu River Basin and shows us that the trends found in the study are similar to those of other eutrophic reservoirs. It also aid in future studies that focus on biodiversity, ecology and conservation and, more broadly, contribute with studies on Brazilian reservoirs.

\section{Acknowledgements}

We would like to thank CAPES and CNPq for fellowships.

\section{References}

AGOSTINHO, A.A., GOMES, L.C., FERNANDEZ, D.R. and SUZUKI, H.I., 2002. Efficiency of fish ladders for Neotropical ichthyofauna. River Research and Applications, vol. 18, no. 3, pp. 299-306. http://dx.doi.org/10.1002/rra.674.

ALMEIDA, V.L.D.S., LARRAZÁBAL, M.E.L.D., MOURA, A.D.N. and MELO-JÚNIOR, M.D., 2006. Rotifera das zonas limnética e litorânea do reservatório de Tapacurá, Pernambuco, Brasil. Iheringia. Série Zoologia, vol. 96, no. 4, pp. 445-451. http://dx.doi.org/10.1590/S0073-47212006000400009.

ALMEIDA, V.L.D.S., MELÃO, M.G. and MOURA, A.D.N., 2012. Plankton diversity and limnological characterization in two shallow tropical urban reservoirs of Pernambuco State, Brazil. Anais da Academia Brasileira de Ciências, vol. 84, no. 2, pp. 537-550. http://dx.doi.org/10.1590/S0001-37652012005000027. PMid:22534751.

ANDERSON, M.J., ELLINGSEN, K.E. and MCARDLE, B.H., 2006. Multivariate dispersion as a measure of beta diversity. Ecology Letters, vol. 9, no. 6, pp. 683-693. http://dx.doi.org/10.1111/j.14610248.2006.00926.x. PMid:16706913.

AOYAGUI, A.S.M., BONECKER, C.C., LANSAC-TÔHA, F.A. and VELHO, L.F.M., 2004. Estrutura e dinâmica dos rotíferos no reservatório de Corumbá, Estado de Goiás, Brasil. Acta Scientiarum. Biological Sciences, vol. 25, no. 1, pp. 31-39.

AUGUSTIN, K.K., ETILÉ, R.N., BLAHOUA, G.K., BI, G.G., KOMELAU, E. and N'DOUBA, V., 2018. Composition and distribution of zooplankton in relationship to environmental parameters in Tropical river (Sassandra River basin, Côte d'Ivoire). Journal of Global Biosciences, vol. 7, no. 5, pp. 5423-5438.

AZEVÊDO, D.J.S., BARBOSA, J.E.L., PORTO, D.E., GOMES, W.I.A. and MOLOZZI, J., 2015. Biotic or abiotic factors: which has greater influence in determining the strucutr of rotifers in semi-arid reservoirs. Acta Limnologica Brasiliensia, vol. 27, no. 1, pp. 60-77. http://dx.doi.org/10.1590/S2179-975X2914.

BEAVER, J.R., SCOTESE, K.C., MANIS, E.E., JUUL, S.T.J., CARROLL, J. and RENICKER, T.R., 2015. Variation in water residence time is the primary determinate of phytoplankton and zooplankton composition in a Pacific Northwest reservoir ecosysten (Lower Snake River, USA). River Systems, vol. 21, no. 4, pp. 241-255. http://dx.doi.org/10.1127/rs/2015/0100.

BEZERRA, M.F.C., SENA, B.A. and EDUARDO, J., 2015. Composição e variabilidade da comunidade de rotifera em um reservatório tropical. Boletim do Instituto de Pesca, vol. 41, no. 3, pp. 493-506.

BOTTRELL, H.H., DUNCAN, A., GLIWICZ, Z.M., GRYGIEREK, E., HERZIG, A., HILLBRICHT-ILKOSKA, A., KURAZAWA, H., LARSSON, P. and WEGLENSKA, T., 1976. A review of some problems in zooplankton production studies. Norwegian Journal of Zooogy, vol. 24, pp. 12-456. 
CASTILHO, M.C.A., WISNIEWSKI, M.J.S., WISNIEWSKI, C. and SILVA, E.S., 2016. Quantifying zooplankton species: use of richness estimators. Iheringia. Série Zoologia, vol. 106, no. 1, pp. e2016011. http://dx.doi.org/10.1590/1678-4766e2016011.

DANTAS-SILVA, L.T. and DANTAS, E.W., 2012. Rotifera of the Três Lagoas Lake Complex, João Pessoa, state of Paraíba, Brazil. Check List, vol. 8, no. 1, pp. 135-137. http://dx.doi. org/10.15560/8.1.135.

DIAS, J.D., SIMÕES, N.R. and BONECKER, C.C., 2012. Zooplankton community resilience and aquatic environmenal stability on aquaculture practices: a study using net cages. Brazilian Journal of Biology $=$ Revista Brasileira de Biologia, vol. 72, no. 1, pp. 1-11. http://dx.doi.org/10.1590/S1519-69842012000100001. PMid:22437379.

DIAS, V.S., LUZ, M.P., MEDERO, G.M. and NASCIMENTO, D.T.F., 2018. An overview of hydropower reservoirs in Brazil: current situation, future perspectives and impacts of climate change. Water, vol. 10, no. 5, pp. 1-13. http://dx.doi.org/10.3390/ w10050592. PMid:30079254.

DUDGEON, D., ARTHINGTON, A.H., GESSNER, M.O., KAWABATA, Z.-I., KNOWLER, D.J., LÉVÊQUE, C., NAIMAN, R.J., PRIEUR-RICHARD, A.-H., SOTO, D., STIASSNY, M.L.J. and SULLIVAN, C.A., 2006. Freshwater biodiversity: importance, threats, status and conservation challenges. Biological Reviews of the Cambridge Philosophical Society, vol. 81, no. 2, pp. 163-182. http://dx.doi.org/10.1017/S1464793105006950. PMid:16336747.

ELER, M.N., PARESCHI, D.C., ESPÍNDOLA, E. and BARBOSA, D., 2003. Ocorrência de Rotífera e sua relação com o estado trófico da água em pesque-pague na bacia do rio Mogi-Guaçu-SP. Boletim Técnico do CEPTA, vol. 16, pp. 41-56.

ESKINAZI SANT'ANNA, E.M., MENEZES, R., COSTA, I.S., PANOSSO, R.F., ARAÚJO, M.F. and ATTAYDE, J.L., 2007. Composição da comunidade zooplanctônica em reservatórios eutróficos do semi-árido do Rio Grande do Norte. Oecologia Brasiliensis, vol. 11, no. 3, pp. 410-421. http://dx.doi.org/10.4257/ oeco.2007.1103.10.

ESKINAZI-SANT'ANNA, E.M., MENEZES, R., COSTA, I.A.S., ARAÚJO, M., PANOSSO, R. and ATTAYDE, J.L., 2013. Zooplankton assemblages in eutrophic reservoirs of the Brazilian semi-arid. Brazilian Journal of Biology $=$. Revista Brasileira de Biologia, vol. 73 , no. 1, pp. 1-12.

ESTEVES, F.A., 2011. Fundamentos de Limnologia. 3. ed. Rio de Janeiro: Interciência, 826 p.

FONTES, A.S., ZUCCHI, M. R., MEDEIROS, Y.D.P. and AZEVEDO, A.E.G., 2011. Estudo da dinâmica do fluxo de água na bacia do Rio Jacuípe por meio de traçadores ambientais. Revista Brasileira de Recursos Hidricos, vol. 16, no. 3, pp. 27-36. http:// dx.doi.org/10.21168/rbrh.v16n3.p27-36

GERALDES, A.M. and GEORGE, C., 2013. Limnological variations of a deep reservoir in periods with distinct rainfall patterns. Acta Limnologica Brasiliensia, vol. 24, no. 4, pp. 417426. http://dx.doi.org/10.1590/S2179-975X2013005000010.

HECK JUNIOR, K.L., VAN-BELLE, G.E. and SIMBERLOFF, D., 1975. Explicit calculation of the rarefaction diversity measurement and the determination of sufficient sample size. Ecology, vol. 56, no. 6, pp. 1459-1461. http://dx.doi.org/10.2307/1934716.

JORGENSEN, S., TUNDISI, J.G. and TUNDISI, T.M., 2013. Handbook of inland aquatic ecosystem management. Boca Raton: CRS Press, $422 \mathrm{p}$.

JÚLIO JÚNIOR, H.F., THOMAZ, S.M., AGOSTINHO, A.A. and LATINI, J.D. 2005. Distribuição e caracterização dos reservatórios. In: L. RODRIGUES, S.M. THOMAZ, A.A. AGOSTINHO and
L.C. GOMES, eds. Biocenoses em reservatórios: padrões espaciais e temporais. São Carlos: RiMa, pp. 1-16.

JUNK, W.J., PIEDADE, M.T.F., LOURIVAL, R., WITTMANN, F., KANDUS, P., LACERDA, L.D., BOZELLI, R.L., ESTEVES, F.A., CUNHA, C. N., MALTCHIK, L., SCHÖNGART, J., SCHAEFFERNOVELLI, Y. and AGOSTINHO, A.A., 2014. Brazilian wetlands: their definition, delineation, and classification for research, sustainable management, and protection. Aquatic Conservation, vol. 24, no. 1, pp. 5-22. http://dx.doi.org/10.1002/ aqc. 2386

KOSTE, W., 1972. Rotatorien aus Gewassen Amazoniens. Amazoniana, vol. 3, pp. 258-505.

KOSTE, W., 1978. Rotatoria. Die Rädertiere Mitteleuropas. Ein Bestimmungswerk, begründet von Max. Voight Überordnung Monogononta II. Tafelband, Gebüder Berlin. Borntraeger, vol. 1, pp. 22-34. http://dx.doi.org/10.1002/iroh.19800650226.

KOSTE, W. and ROBERTON, B., 1983. Taxonomic studies of the Rotifera (Phylum Aschelminthes) from a Central Amazonian várzea lake, Lago Camaleão -lha Machantaria, Rio Solimões, Amazonas, Brazil. Amazoniana, vol. 8, no. 1, pp. 225-254.

LANSAC-TÔHA, F.A., BONECKER, C.C., VELHO, L.F.M., SIMÕES, N.R., DIAS, J.D., ALVES, G.M. and TAKAHASHI, E.M., 2009. Biodiversity of zooplankton communities in the Upper Paraná River floodplain: interannual variation from longterm studies. Brazilian Journal of Biology $=$ Revista Brasileira de Biologia, vol. 69, no. 2, suppl., pp. 539-549. http://dx.doi. org/10.1590/S1519-69842009000300009. PMid:19738961.

LANSAC-TÔHA, F.A., VELHO, L.F.M. and BONECKER, C.C., 2004. Composition, species richness and abundance of the zooplankton community. In: S.M. THOMAZ, A.A. AGOSTINHO and N.S. HAHN, eds. The Upper Paraná River and its floodplain: physical aspects, ecology and conservation. Leiden: Backhuys Publishers, pp. 145-190.

LEGENDRE, P., DALLOT, S. and LEGENDRE, L., 1985. Succession of species within a community: chronological clustering, with applications to marine and freshwater zooplankton. American Naturalist, vol. 125, no. 2, pp. 257-288. http://dx.doi. org/10.1086/284340.

LEMKE, A.M. and BENKE, A.C., 2009. Spatial and temporal patterns of microcrustacean assemblage structure and secondary production in a wetland ecosystem. Freshwater Biology, vol. 54, no. 7, pp. 1406-1426. http://dx.doi.org/10.1111/j.13652427.2009.02193.x.

MANTOVANO, T., ARRIEIRA, R.L., SCHWIND, L.T.F., BONECKER, C.C. and LANSAC-TÔHA, F.A., 2015. Rotifer community structure along a stretch under the influence of dams in the Upper Paraná River floodplain. Acta Scientiarum. Biological Sciences, vol. 37, no. 3, pp. 281-289. http://dx.doi.org/10.4025/ actascibiolsci.v37i3.27759.

MARGALEF, R., 1983. Limnologia. Barcelona: Edição Omega, $1010 \mathrm{p}$.

MARZOLF, G.R., 1990. Reservoirs as environments for zooplankton. In: K.W. THORNTON, B.L. KIMMEL and E. PAYNE, eds. Reservoir limnology: ecological perspectives. New York: John Wiley \& Sons, pp. 195-208.

MELO-JÚNIOR, M.D., ALMEIDA, V.L.D.S., NEUMANN-LEITÃO, S., PARANAGUÁ, M.N. and MOURA, A.D.N., 2007. O estado da arte da biodiversidade de rotíferos planctônicos de ecossistemas límnicos de Pernambuco. Biota Neotropica, vol. 7, no. 3, pp. 109-117. http://dx.doi.org/10.1590/S1676-06032007000300013.

NANDINI, S., RAMÍREZ-GARCIA, P., SARMA, S.S.S. and GUTIERREZ-OCHOA, R., 2019. Planktonic indicators of water quality: a case study in the Amacuzac River basin (State 
of Morelos, Mexico). River Research and Applications, vol. 35, no. 3, pp. 268-279. http://dx.doi.org/10.1002/rra.3401.

NOGRADY, T., WALLACE, R.L. and SNELL, T.W., 1993. Rotifera: biology, ecology and sistematics. In: H.L. DUMONT, ed. Guides of the identification of the microinvertebrates of the continental waters. The Hague: SPB Academic Publishing, $142 \mathrm{p}$.

NOGRADY, T. and POURRIOT, R., 1995. Rotifera: the Notommatidae. In: H.L. DUMONT, ed. Guides to the identification of the microinvertebrates of the continental waters of the world. The Hague: SPB Academics, 248 p.

NOGUEIRA, C., 2006. Diversidade e padrões de distribuição da fauna de lagartos do Cerrado. São Paulo: Universidade de São Paulo, 295 p. Tese de Doutorado em Ecologia.

NOGUEIRA, M.G., 2001. Zooplankton composition, dominance and abundance as indicators of environmental compartimentalization in Jurumirim reservoir (Paranapanema river), São Paulo, Brazil. Hydrobiologia, vol. 455, no. 1-3, pp. 1-18. http://dx.doi. org/10.1023/A:1011946708757.

OBERTEGGER, U., FLAIM, G., BRAIONI, M.G., SOMMARUGA, R., CORRADINI, F. and BORSATO, A., 2007. Water residence time as a driving force of zooplankton structure and succession. Aquatic Sciences, vol. 69, no. 4, pp. 575-583. http://dx.doi. org/10.1007/s00027-007-0924-z.

OKSANEN, J., BLANCHET, F.G. and KINDT, R., 2013 [viewed 22 July 2019]. Vegan: Community Ecology Package. R package version 3.0 [online]. Vienna: R Foundation for Statistical Computing. Available from: http://vegan.r-forge.r-project.org/

OKULU, E.O., TOLE, M., KITERESI, L.I. and BOUILLON, S., 2016. The response of phytoplankton and zooplankton to river damming in three cascading reservoirs of the Tana River, Kenya. Lakes \& Reservoirs, vol. 21, no. 1, pp. 114-132. http://dx.doi. org/10.1111/lre.12127.

PAGGI, J.S., 1989. Rotíferos de algunas provincias del noroeste argentino. Hydrobiologia, vol. 22, no. 3, pp. 223-238.

PEDROZO, C.S., SCHNECK, F., SCHWARZBOLD, A. and FARIAS, R.N., 2012. Zooplankton community responses to the impoundment of Dona Francisca reservoir, Rio Grande do Sul, Brazil. Iheringia. Série Zoologia, vol. 102, no. 2, pp. 42-149. http://dx.doi.org/10.1590/S0073-47212012000200005.

R DEVELOPMENT CORE TEAM, 2017. R: a language and environment for statistical computing. Vienna: R Foundation for Statistical Computing.

ROCHA, O., MATSUMURA-TUNDISI, T., ESPINDOLA, E.L.G., ROCHE, A. and RIETZLER, C. 1999. Ecological theory applied to reservoir zooplankton. In: J.G. TUNDISI and M. STRAŠKRABA, eds. Theoretical reservoir ecology and its applications. São Carlos: International Institute of Ecology, pp. 457-476.

RODGHER, S., ESPÍNDOLA, E.L.G., ROCHA, O., FRACÁCIO, R., PEREIRA, R.H.G. and RODRIGUES, M.H.S., 2005. Limnological and Ecotoxicological Studies In the Cascade of Reservoirsin the Tietê River (São Paulo, Brazil). Brazilian Journal of Biology = Revista Brasileira de Biologia, vol. 65, no. 4, pp. 697-710. http:// dx.doi.org/10.1590/S1519-69842005000400017. PMid:16532194.

SAMPAIO, E.V., ROCHA, O., MATSUMURA-TUNDISI, T. and TUNDISI, J.G., 2002. Composition and abundance of zooplankton in the limnetic zone of seven reservoir of Paranapanema River, Brazil. Brazilian Journal of Biology $=$ Revista Brasileira de Biologia, vol. 62, no. 3, pp. 525-545. http://dx.doi.org/10.1590/ S1519-69842002000300018.

SCHORK, G. and ZANIBONI-FILHO, E., 2018. Influence of spatial gradiente caused by a large dam on fish assemblage in a subtropical reservoir - Upper Uruguay River. Boletim do Instituto de Pesca, vol. 44, no., 2, pp. e236.

SEGERS, H., 1995. Rotifera: the Lecanidae. In: H.L. DUMONT, ed. Guides to the identification of the microinvertebrates of the continental waters of the world. The Hague: SPB Academics, $226 \mathrm{p}$.

SERAFIM-JÚNIOR, M., BONECKER, C.C., ROSSA, D.C., LANSAC-TÔHA, F.A. and COSTA, C.L., 2003. Rotifers of the upper Paraná river flood plain: additions to the checklist. Brazilian Journal of Biology = Revista Brasileira de Biologia, vol. 63, no. 2, pp. 207-212. http://dx.doi.org/10.1590/S151969842003000200005. PMid:14509842.

SERAFIM-JÚNIOR, M., NEVES, G.P., BRITO, L. and GHIDINI, A.R., 2016. Continuity effects on rotifers and microcrustaceans caused by the construction of a downstream reservoir in a cascade series (Iguaçu River, Brazil). Brazilian Journal of Biology = Revista Brasileira de Biologia, vol. 76, no. 2, pp. 279-291. http://dx.doi. org/10.1590/1519-6984.00314. PMid:26983084.

SERAFIM-JÚNIOR, M., PERBICHE-NEVES, G., BRITO, L. and GHIDINI, A.R., 2006. Zooplâncton do rio Itajaí-Açú a jusante da cidade de Blumenau, Santa Catarina, Brasil. Estudos de Biologia, vol. 28, no. 65, pp. 41-50. http://dx.doi.org/10.7213/ reb.v28i65.22167. PMid:14509842.

SERAFIM-JUNIOR, M., PERBICHE-NEVES, G., BRITO, L., GHIDINI, A.R. and CASANOVA, S.M.C., 2010. Variação espaço-temporal de Rotifera em um reservatório eutrofizado no sul do Brasil. Iheringia. Série Zoologia, vol. 100, no. 3, pp. 233-241. http://dx.doi.org/10.1590/S0073-47212010000300008.

SILVA BRITO, M.T.S., NASCIMENTO FILHO, S.L., ALMEIDA, V.L.S., NEUMANN LEITÃO, S. and MELO JÚNIOR, M., 2018. Zooplankton assemblages under drought period stressors in two reservoirs from semi-arid Brazil. Fundamental and Applied Limnology, vol. 19, no. 2, pp. 99-110.

SIMPSON, G.L., 2016 [viewed 22 July 2019]. Permute: Functions for generating restricted permutations of data. R package version 0.9-4 [online]. Vienna: R Foundation for Statistical Computing. Available from: https://cran.r-project.org/package=permute

SOKAL, R.R. and ROHLF, F.J., 1995. Biometry. New York: W.H. Freeman, 887 p.

TAKAHASHI, E.M., LANSAC-TÔHA, F.A., DIAS, J.D. and BONECKER, C.C., 2014. Daily variation of zooplankton abundance and evenness in the Rosana reservoir, Brazil: biotic and abiotic inferences. Iheringia. Série Zoologia, vol. 104, no. 1, pp. 21-31. http://dx.doi.org/10.1590/1678-4766201410412131.

VÖRÖSMARTY, C.J., MCINTYRE, P.B., GESSNER, M.O., DUDGEON, D., PRUSEVICH, A., GREEN, P., GLIDDEN, S., BUNN, S.E., SULLIVAN, C.A., LIERMANN, C.R. and DAVIES, P.M., 2010. Global threats to human water security and river biodiversity. Nature, vol. 467, no. 7315, pp. 555-561. http:// dx.doi.org/10.1038/nature09440. PMid:20882010.

XUE, Y., CHEN, H., YANG, J.R., LIU, M., HUANG, B. and YANG, J., 2018. Distinct patterns and processes of abundant and rare eukaryotic plankton communities following a reservoir cyanobacterial bloom. The ISME Journal, vol. 12, no. 9, pp. 2263-2277. http://dx.doi.org/10.1038/s41396-018-0159-0. PMid:29899512.

ZAGANINI, R.L., PERBICHE-NEVES, G., NALIATO, D.A.O. and CARVALHO, E.D., 2011. Baixa diversidade de zooplâncton na desembocadura de uma represa eutrófica (SP, Brasil): reflexo da poluição? Estudos de Biologia, vol. 32-33, no. 76-81, pp. 1724. http://dx.doi.org/10.7213/reb.v32i76/81.22860. 